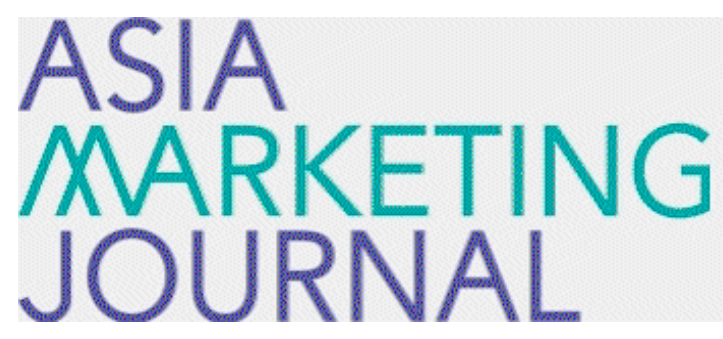

ASIA MARKETING JOURNAL

Volume 18 | Issue 3

Article 2

$10-31-2016$

\title{
The Impact of Product Involvement on Reciprocal Effect in Co- branding
}

Chia-Lin Lee

Follow this and additional works at: https://amj.kma.re.kr/journal

Part of the Marketing Commons

\section{Recommended Citation}

Lee, Chia-Lin (2016) "The Impact of Product Involvement on Reciprocal Effect in Co-branding," Asia Marketing Journal: Vol. 18 : Iss. 3 , Article 2.

Available at: https://doi.org/10.15830/amj.2016.18.3.19

This Article is brought to you for free and open access by Asia Marketing Journal. It has been accepted for inclusion in Asia Marketing Journal by an authorized editor of Asia Marketing Journal. 


\title{
The Impact of Product Involvement on Reciprocal Effect in Co-branding
}

Chia-Lin Lee*

\begin{abstract}
Product involvement is an important factor in consumer evaluation of co-branding. However, academic discussions over this factor have largely been neglected. This paper bridges this gap and investigates how product involvement moderates the strength of the reciprocal effect on each brand partner. We validate two theory-driven propositions by using a theoretical modeling approach. Proposition 1 explains that the negative reciprocal effect on partnering brands is stronger in the scenario of higher-involved categories than in lower-involved categories. Proposition 2 argues that the positive reciprocal effect on partnering brands can be more significant in the case of lower-involved categories than in higher-involved categories. To the best of our knowledge, we are the first to explore the influence of product involvement on reciprocal effects in the scenario of a moderately-incongruent co-branding alliance.
\end{abstract}

Key words: Co-branding, Product Involvement, Reciprocal Effect

\section{Introduction}

Co-branding is defined as "a composite brand extension in which two brand names are combined to create a composite brand name for a new product or service" (Park et al. 1996). There are essentially two types of co-brands: tangible co-branded products and intangible co-branded services. ${ }^{1)}$ Tangible co-branded products include horizontal co-branding, a strategy in which the partnering brands are at the same step in the value chain (e.g., the Sony-Ericsson mobile phone), as well as ingredient co-branding, in which two integral parts comprise one product (e.g., the HP notebooks featuring "Intel Inside"; cf. Walchli 2015). Examples of co-branded services include Dual-Branding (Levin and

\footnotetext{
* Assistant Professor, Department of Business Administration, National Chengchi University, Taiwan (clee@nccu.edu.tw)

1) In this research, we use the terms "co-branded product/service" and "joint product/service" interchangeably to represent the product/service released in a co-branding alliance.
} 
Levin 2000; e.g., Kentucky Fried Chicken (KFC) and $\mathrm{A} \& \mathrm{~W}$ restaurants) and retail $\mathrm{co}^{-}$ branding (e.g., Walmart and Starbucks). Table 1 lists and summarizes some current prominent co-branding examples in different types of products and services.

It is evident that co-branded products are distributed over many different categories. However, not all co-branded products achieve success when forming a co-branding alliance (Cao and Sorescu 2013). Perhaps the most famous example of a co-branding failure is the BenQSiemens mobile phone. In fact, ( $\left.\mathrm{co}^{-}\right)$brand strategies may not be successful throughout a particular product category. We believe that the success or failure of co-branding can be $\mathrm{ex}^{-}$ plained by such factors as the strategic intent of one brand partner to form a co-branding alliance (e.g., Rao and Ruekert 1994; Washburn et al. 2000) or consumer evaluations of the $\mathrm{co}^{-}$ brand and the partnering brands (e.g., Park et al. 1996; Simonin and Ruth 1998).

We argue that the literature on co-branding success remains incomplete, since discussions on consumer involvement have largely been neglected. A more detailed discussion of consumer evaluation as an indispensable factor in co-branding research is particularly needed

〈Table 1〉 Co-branding Examples

\begin{tabular}{|l|c|}
\hline \multicolumn{1}{|c|}{ Examples } & Product/Service \\
\hline Gillette razor and Noxzema moisturizer & Product \\
\hline HP/Lenovo laptop with Intel-inside & Product \\
\hline Apple iPod/Nike Sport kit & Product \\
\hline Philips Sonicare Crest toothbrush & Product \\
\hline Ben \& Jerry and Heath Bar Crunch ice cream & Product \\
\hline Puma-Ferrari shoes & Product \\
\hline Goretex-Timberland shoes & Product \\
\hline Teflon-WMF Cookware & Product \\
\hline Beechnut baby foods und Chiquita Bananas & Product \\
\hline Kellogg's Pop Tarts woth Smucker's fruit filling & Product \\
\hline Philadelphia Milka Chocolate & Product \\
\hline Tuna Helper Complete with Starkist Tuna & Product \\
\hline Duncan Hines Fun Frosters with Nestlé Crunch Candy & Product \\
\hline KFC \& A\&W restaurant & Service \\
\hline DB Bahn with SNCF train from Frankfurt to Paris & Service \\
\hline Starbucks with Barnes \& Nobel & Service \\
\hline Tim Horton with Wendy restaurant & Service \\
\hline Crowne Plaza Paramus with Bonefish Grill & Service \\
\hline
\end{tabular}


with respect to the evaluation of co-branding. However, to our knowledge, only a few studies have examined the influence of consumer involvement on consumer evaluation (e.g., Helmig et al. 2007; Samuelsen et al. 2014). Therefore, the objective of the present research is to bridge this gap.

Specifically, we focus on one type of involvement: consumer product involvement. Consumer product involvement is a crucial factor in consumer evaluation (Aaker and Keller 1990). Throughout this research, consumer product involvement is defined as "consumers' perceived relevance of the co-brand's product category to their needs and values" (Nkwocha et al. 2005, p. 51). For example, beverages and batteries are often recognized as lower-involved products, while computers and smart-phones are often considered to be higher-involved products.

This study aims to answer an important question: How does consumer product involvement moderate the strength of the reciprocal effect on each partnering brand? The term "reciprocal effect" is referred to as the influences that the attitudes toward the co-brand have on each of the allying brands. We explore whether the higher-involved and lower-involved categories affect the magnitude of negative (in the case of an unsuccessful co-brand) or positive (in the case of a successful co-brand) reciprocal effect.

This study contributes to the co-branding literature by exploring the moderating influence of product involvement on the reciprocal effects in the scenario of a moderately-incongruent brand pair (cf. Walchli et al. 2007). This study also assists brand managers of multicategory corporations (e.g., Sony) to choose the appropriate product category for developing a co-branding partnership. Furthermore, our work complements previous discussions over reciprocal effects in co-branding (e.g., Radighieri et al. 2014; Cunha Jr. et al. 2015). For instance, we can add to Cunha Jr. et al.'s (2015, p. 1288) findings and conclude: For a stronger positive reciprocal effect on it, the less-known brand (Prime foods) should partner with a well-known brand (e.g., Kellogg's) to release a low-involved product (e.g., corn flakes), and the name of less-known brand should appear only at the end of a co-brand advertisement.

The remainder of this research is organized as follows. Section 2 reviews existing relevant literature on co-branding success and consumer involvement, and offers two research propositions. Section 3 provides the details of a proposed mathematical analytical model for proving the propositions, and we show the proof in section 4. Finally, we present our conclusions, the contributions of the study, and extensions to future research in section 5 . 


\section{Literature Review and Propositions}

\subsection{Review of the Relevant Literature}

To our knowledge, co-branding success may be analyzed from two major perspectives: the consumer behavior framework and the strategic alliance framework. From a strategic alliance perspective, for example, Bucklin and Sengupta (1993) apply the theory of inter-organizational exchange (e.g., Cook 1977) in analyzing the co-branding alliance, and Mohr and Spekman (1994) address the importance of mutual trust. Additionally, signaling theory (Spence 1973) has been adopted by several scholars (e.g., Rao and Ruekert 1994; Washburn et al. 2000; Bengtsson and Servais 2005) to explain the function of the brand name in a co-branding alliance.

Compared with a small number of studies from the strategic alliance framework, a rich vein of literature has focused on the attitudinal favorability of the co-brand and on the post-alliance attitudinal evaluation of each of the partnering brands. The most crucial factor in determining the attitudinal favorability of a co-brand may be the "fit." This term was first defined by Aaker and Keller (1990) and, to our knowledge, Park et al. (1996) were the first to use apply term to the field of co-branding. Specifically, the authors defined the term "product fit" as the existence of attribute complementarity. Except the product fit, Simonin and Ruth (1998) defined a good brand fit as a high level of consistency in the brand images of the host and ingredient brands (e.g., Louis Vuitton and Montblanc). Aside from "product fit" and "brand fit," there exist other types of "fit" (e.g., the fit of the country-of-origin image, Lee et al. 2013; the fit of brand personality, Van der Lans et al. 2014).

In addition to the attitudinal favorability of the co-brand, the other important factor determining co-branding success is the post-alliance evaluation of each of the partnering brands. It is commonly accepted that the post-alliance attitudes toward the partnering brands are directly influenced by "the strength of reciprocal effects" (Park et al. 1996; Baumgarth 2004; Rodrigue and Biswas 2004). To our knowledge, researchers often examine reciprocal effects at two levels: the attitude level (e.g., Simonin and Ruth 1998: Baumgarth 2004) and the belief level (e.g., Hillyer and Tikoo 1995; Geylani et al. 2008).

Simonin and Ruth (1998) were the first to find that reciprocal effect may exist at the attitude level. Washburn et al. (2000) report that a weaker brand in terms of brand equity could gain a positive reciprocal effect if it allies with a stronger brand. Swaminathan et al. (2011) and Radighieri et al. (2013) also investigated the different reciprocal effects on partnering brands by using panel data and by performing experi- 
ments, respectively. The above-mentioned studies focused on reciprocal effects at the attitude level; to our knowledge, however, only two studies have investigated reciprocal effects at the belief level (belief revisions). Park et al. (1996) argue that a co-brand with a good product fit may cause a positive reciprocal effect on consumer evaluations of the important attributes of partnering brands. Geylani et al. (2008) utilize a theoretical mathematical modeling approach to show that consumers' attribute beliefs may encounter positive or negative reciprocal effects (i.e., belief revision). We argue that belief revision is therefore related to reciprocal effects at the attitude level; thus, in our model, consumers' reciprocal effects at the attitude level are formulated by connecting to those effects at the belief level. Moreover, previous research suggests that a few factors could moderate the strength of reciprocal effects. For example, Hillyer and Tikoo (1995) and Park et al. (1996) report that the order of the brand names in co-branding may influence the magnitude of reciprocal effects across the allying brands - the header (or primary) brand (Sony in Sony - Ericsson) may have a stronger reciprocal effect than the modifier (or secondary) brand (e.g., Ericsson in Sony - Ericsson). Brand familiarity (Simonin and Ruth 1998) is also a moderator of reciprocal effects: That is, a lower level of brand familiarity with one brand may generate a stronger reciprocal effect on that brand.
Finally, some decisive factors, such as the country-of-origin effect (Voss and Tansuhaj 1999), association transfer (James 2005), similarity-of-brand associations (Van der Lans et al. 2014), and consumer involvements (Helmig et al. 2007; Vijay et al. 2012; Samuelsen et al. 2014), remain in terms of studies that have used the consumer evaluation framework. A more detailed summary regarding the most important factors for co-branding success is presented in Table 2.

In summary, Table 2 demonstrates that theoretical and empirical validations regarding consumer involvement are relatively limited, although there is a profusion of literature on co-branding success from the perspective of consumer evaluation (e.g., Helmig et al. 2008; Samuelsen et al. 2014). Since consumer involvement is an interesting and important research topic in the field of co-branding (Vaidyanathan and Aggarwal 2000), this crucial factor must be taken into account when evaluating co-branding success.

The concept of involvement, which has been connected to marketing by Krugman (1966), consists of product involvement (e.g., Michaelidou and Dibb 2006), purchasing involvement (e.g., Mittal 1989; Helmig et al. 2007), task involvement (Tyebjee 1979), advertising involvement (Zaickhowsky 1985), and situational involvement (Samuelsen et al. 2014). In the field of brand extension, there has been a great deal of discussion about consumer involvement; most stud- 
〈Table 2〉 Co-branding Success Factors

\begin{tabular}{|l|l|l|}
\hline \multicolumn{1}{|c|}{ Success factor } & \multicolumn{1}{|c|}{ Author(s); Year } & \multicolumn{1}{c|}{ Framework } \\
\hline brand fit: brand awareness & $\begin{array}{l}\text { Simonin and Ruth; 1998 } \\
\text { Voss and Tansuhaj; 1999 } \\
\text { Cao and Sorescu; 2013 }\end{array}$ & Consumer Behavior \\
\hline product fit & $\begin{array}{l}\text { Park et al.; 1996 } \\
\text { Simonin and Ruth; 1998 }\end{array}$ & Consumer Behavior \\
\hline country of origin fit between brands & $\begin{array}{l}\text { Voss and Tansuhaj; 1999 } \\
\text { Lee, et al.; 2013 }\end{array}$ & Consumer Behavior \\
\hline Brand equity & Washburn et al., 2004 & Strategic Alliance \\
\hline $\begin{array}{l}\text { Company culture and management style are } \\
\text { the same for the allying brand }\end{array}$ & Bucklin and Sengupta; 1993 & Strategic Alliance \\
\hline Mutual benefit: resource fit between brands & Venkatesh et al.; 2000 & Strategic Alliance \\
\hline Incongruence of the two brands & $\begin{array}{l}\text { Walchli; 2007 } \\
\text { Sreejesh; 2012 }\end{array}$ & Consumer Behavior \\
\hline $\begin{array}{l}\text { Similarity of brand associations } \\
\text { Eames; 2005 } \\
\text { Van der Lans et al.; 2014 } \\
\text { only associated with one alliance }\end{array}$ & $\begin{array}{l}\text { Cao and Sorescu; 2013 } \\
\text { Newmeyer et al.; 2014 }\end{array}$ & Consumer Behavior \\
\hline Positive reciprocal Effect on brand partners & Simonin and Ruth; 1998 & Consumer Behavior \\
\hline $\begin{array}{l}\text { High brand familiarity of the allying brands } \\
\text { (stronger positive reciprocal effect) }\end{array}$ & Simonin and Ruth; 1998 & Consumer Behavior \\
\hline purchase intention & Swaminathan et al.; 2011 & Consumer Behavior \\
\hline new-product-brand-fit & Bouten et al.; 2011 & Consumer Behavior \\
\hline Purchasing Involvement & Helmig et al.; 2007 & Consumer Behavior \\
\hline $\begin{array}{l}\text { High situational Involvement for the } \\
\text { co-branded product }\end{array}$ & Samuelsen et al.; 2014 & Consumer Behavior \\
\hline
\end{tabular}

ies have focused on how this type of involvement affects consumer evaluations of the extended products if the existing and the extended ones are different (e.g., Nkwocha et al. 2005).

In the field of co-branding research, Helmig et al. (2007) presented a seminal work that investigates the impact of consumer involvement in co-branding evaluation. Through the use of experiments, Helmig et al. (2007) posited that consumers with a high degree of purchase involvement will have greater intentions to try the new co-branded products, given that those co-branded products are complementary and make more sense to consumers than do those with low involvement. Based on congruence theory (Meyers-Levy and Tybout 1989), Walchli (2007) and Sreejesh (2012) both report that under a high-involvement processing condition, a brand alliance that reveals a moderate differ- 
ence (e.g., Business Week - The Wall Street Journal) leads to a more favorable evaluation. From the perspective of ingredient co-branding, Vijay et al. (2012) argue that a highly involved host-brand category could have a positive effect on the product trial and on purchase intentions, but a highly involved ingredient- brand category does not. From the viewpoint of symbolic $\mathrm{co}^{-}$ branding, Mazodier and Merunka (2012) used fictitious co-branded mobile phones to posit that there is a weak relation between self-congruity and the purchase intention of the co-branded product in the less-involved case, and vice versa. The authors concluded that a brand should select its partner from the consumers' highly involved product category. Samuelsen et al. (2014) argue that when the co-brand information is deemed to be relevant to consumers' personal interests or needs (e.g., in the case of highsituational involvement, the co-brand is locally released without delay, while in the low- situational involvement scenario, the co-brand is released in two years and in other countries), the impacts of fit on consumers' attitudes toward the co-brand will be more significant. To summarize, the consumers with high situational involvement (e.g., active runners) would $\mathrm{ex}^{-}$ hibit a more positive attitude toward the $\mathrm{co}^{-}$ brand (e.g., Nike/iPod) with a stronger argument as well as a better fit.

The above studies, however, have completely ignored an important question: Do different levels of product involvement affect co-branding success? That is, since consumer product involvement is a crucial factor in brand evaluation (Aaker and Keller 1990) and product involvement has proved to be a crucial factor in moderating the affect transfer between existing and extended categories (cf. Nkwocha et al. 2005), how do consumers' varying degrees of product involvement influence their attitudes toward the co-brand and toward the partnering brands? In this research, we try to investigate whether product involvement moderates the strength of consumers' reciprocal effect on the partnering brands.

\subsection{Research Propositions}

In this sub-section, we provide two propositions that, to our knowledge, have not yet been investigated. Note that this sub-section discusses the moderating impact of consumer involvement on the magnitude of reciprocal effect at the belief level, and that, hereafter, we always assume that the co-brand's product category is the same as that of the partnering brands (i.e., horizontal brand alliances; e.g., the Sony-Ericsson mobile phone is in the same category as Sony and Ericsson).

The first proposition is relevant to the negative reciprocal effect. We argue that the negative reciprocal effect that is derived from an unfavorably evaluated co-brand on a partnering brand will be more significant in the scenario of a higher-involved category than in the case 
of a lower-involved category for the following reason: According to Goldsmith and Flynn (1992), in the case of a higher-involved product category (e.g., computers), consumers may act aggressively in collecting relevant information because they consider the buying decision to be a serious one that is relevant to their needs and values. Moreover, those products are usually higherpriced and are considered to be durable goods (Laurent and Kapferer 1985); thus, the perceived risk of a misguided purchase is high (Rothschild 1979). Therefore, when the co-branded product performs badly, consumers tend to experience a process of "cognitive dissonance" and react more negatively in this case than in the lower-involved case. Proposition 1 is stated as follows:

\subsubsection{Proposition 1}

When there is a higher degree of product involvement in co-branding, the magnitude of the negative reciprocal effect on each of the partnering brands is much larger.

The managerial implication behind Proposition 1 is that the co-branding failure may cause a stronger negative impact on the existing brand image among consumers if a brand (firm) chooses the more expensive product in developing a co-branding alliance. In contrast, our second proposition is relevant to the positive reciprocal effect. We posit that the positive re- ciprocal effect that is derived from a favorably evaluated co-brand on a partnering brand will be more significant in the scenario of a lowerinvolved category than in the case of a higherinvolved category. In the research field of brand extension, Nkwocha et al. (2005) report that when there is a good fit in terms of complementarity between existing and extended categories, consumers will have a stronger positive effect of affect transfer between the two categories in a lower-involvement case than that which occurs in the higher-involvement case. Since we assume that a good fit (attribute complementarity) exists in our model (please see section 3) and that co-branding is one type of brand extension (Hadjicharalambous 2013), we argue that the findings in the field of brand extension can fully transfer to the field of co-branding. Proposition 2 illustrates our argument:

\subsubsection{Proposition 2}

When there is a lesser degree of product involvement in co-branding, the magnitude of the positive reciprocal effect on each of the partnering brands is much larger.

The managerial implication behind Proposition 2 is that co-branding success in terms of a favorably evaluated co-brand may lead to a stronger positive impact on the existing brand image for one brand, if the brand (firm) selects the lowerinvolved product to develop a co-branding alliance. 


\section{Model}

In this section, we use a theoretical and mathematical modeling approach to prove the two propositions for offering managers strategic intent of employing a co-branding strategy (cf. Moorthy 1993). We use the expectancy-value model (cf. Bass and Talarzyk 1972) to formulate consumers' reciprocal effects. To begin, supposing that $A$ and $B$ are the prospective brand alliance partners and that there are several product categories in $A(B)$ 's market offering. However $A$ and $B$ only choose one product category (e.g., smart-phone) to form a horizontal co-branding alliance. Assuming that there are two segments of sizes, $M_{F(1)}>0(F \in\{A, B\})$, and we use $U(U \in\{a, b\})$ to indicate each brand's existing market (i.e., segments). Supposing that at time point $i=1$, a co-branding alliance is formed; at time $i=2$, the first co-branded product is released and all the consumers have already experienced the co-branded product. That is, consumers' reciprocal effects occur, for each brand, at $i=2$.

Consumer preference (i.e., attitudinal evaluations) at time $i$ is formulated as a relative value consisting of $U$ 's relative weights of attribute importance $w^{H, U} \in(0,1)$ and $U^{\prime}$ 's belief of each attribute of each brand $P_{F(i)}^{H, U}>0$. Notice that $H \in\{x, y\}$ denotes the two attributes; $x$ represents durability, and $y$ represents style. By using the expectancy-value model,
U's preference value (i.e., consumer attitudinal evaluation), $\Phi_{F(i)}^{U}$, can be formulated as

$$
\Phi_{F(i)}^{U}=\sum_{H} w^{H, U} \times P_{F(i)}^{H, U} .
$$

In the following, we will formulate three types of consumer evaluations by utilizing Eq. (1): pre-alliance evaluation, co-branding evaluation, and post-alliance evaluation. Assuming that $A$ $(B)$ is known by all consumers at the two segments that it performs well on $x(y)$ but not on $y(x)$ at $i=1$. That is,

$$
\begin{aligned}
& P_{A(1)}^{x}>P_{B(1)}^{x}, \\
& P_{B(1)}^{y}>P_{A(1)}^{y} .
\end{aligned}
$$

We then use $w^{H, U}$ to capture the betweensegment heterogeneity. That implies

$$
\begin{aligned}
& w^{x, a}>w^{y, a}, \text { where } \sum_{H} w^{H, a}=1, \\
& w^{y, b}>w^{x, b}, \text { where } \sum_{H} w^{H, b}=1 .
\end{aligned}
$$

Eqs. (4) and (5) show that segment a considers attribute $x$ to be more important while segment $b$ thinks of $y$ as more important. Combining Eqs. (2) to (5) together, we can show

$$
\begin{aligned}
& \Phi_{A(1)}^{a}>\Phi_{B(1)}^{a}, \\
& \Phi_{B(1)}^{b}>\Phi_{A(1)}^{b} .
\end{aligned}
$$


Inequalities (6) and (7) show consumers' prealliance evaluations. By using the theory of information integration (Anderson 1981), we formulate consumers' co-branding evaluations as a process that combines existing beliefs about the two brands. So, we use $\kappa_{F}^{H, U}\left(1 \geq \kappa_{F}^{H, U}\right.$ $\geq 0$ ) to denote the weight of existing beliefs about the two brands. That is, their perceived attribute beliefs of the co-branded products (i.e., co-branding beliefs) can be modeled as

$$
\begin{aligned}
& P_{A B(1)}^{x}=\kappa_{A}^{x, U} P_{A(1)}^{x}+\left(1-\kappa_{A}^{x, U}\right) P_{B(1)}^{x}, \\
& P_{A B(1)}^{y}=\kappa_{B}^{y, U} P_{A(1)}^{y}+\left(1-\kappa_{B}^{y, U}\right) P_{B(1)}^{y} .
\end{aligned}
$$

Finally, consumers' post-alliance evaluations of each brand at $i=2$ modeled as a composition of consumers' pre-alliance evaluations and co-branding evaluations. So, the post-alliance beliefs can be modeled as (cf. Geylani et al., 2008).

$$
\begin{aligned}
P_{F(2)}^{H, U}= & \gamma_{F}^{H, U} \times P_{A B(1)}^{H} \\
& +\left(1-\gamma_{F}^{H, U}\right) \times P_{F(1)}^{H}
\end{aligned}
$$

In Eq, (10), we use the updating weight, $\gamma_{F}^{H, U}$, to measure the degree of consumers' reciprocal effects on the belief levels of the two partnering brands. Consumers' preference value (i.e., consumer attitudinal evaluation) at $i=2$ are expressed as

$$
\Phi_{F(2)}^{U}=\sum_{H} w^{H, U} \times P_{F(2)}^{H, U}
$$

Note that the example used in our model is a moderately-incongruent brand pair, and we do not further investigate whether our propositions are still valid in the extremely-incongruent and similar (congruent) cases. The underlying reason is that, due to the lack of a positive belief revision, the alliance may encounter a failure in those two cases (Lee and Decker 2016). Thus, consumers' post-alliance beliefs (Eq. (10)) will be the same as their pre-alliance beliefs, and reciprocal effect may not occur in those two cases.

\section{Proof}

In the following we will only discuss a's reciprocal effect to $A$. So, hereafter we drop the segment index, $U$. Besides, hereafter we will discuss two types of reciprocal effects: "reciprocal effects on the belief level," and "reciprocal effects on the attitude level." So, we let $S^{\alpha}$ and $S^{\beta}$ be the magnitude of segment a's reciprocal on the belief of attribute $x$ and the respective changes on their attitude level, respectively. That is

$$
\begin{aligned}
& S^{\alpha}=P_{A(1)}^{x}-P_{A(2)}^{x}, \\
& S^{\beta}=\Phi_{A(1)}^{a}-\Phi_{A(2)}^{a} .
\end{aligned}
$$

To prove Prop. 1, due to the need of parsimony of this model, co-branding beliefs are as- 
sumed to be

$$
\begin{aligned}
& P_{A B(1)}^{x}=\operatorname{Min}\left[P_{A(1)}^{x}, P_{B(1)}^{x}\right], \\
& P_{A B(1)}^{y}=\operatorname{Min}\left[P_{A(1)}^{y}, P_{B(1)}^{y}\right] .
\end{aligned}
$$

The connectionist models of brand associations (e.g., Janiszewski and van Osselaer 2000) reported that the stronger the cue, the larger the accessibility of the beliefs derived from consumers' memory. Thus, we argue that the updating weight in Eq. (10) is connected to consumer involvements. As mentioned in Section 2, Goldsmith and Flynn (1992) posited that, in a higher-involved case, consumers may be much more aggressively in collecting attribute information. Thus, in the highly-involved case, consumers can consider negative co-branding information more important. Therefore, to prove Prop. 1, we designate $T$ as the differential level of product involvement, and assume that $\gamma_{A}^{x}$ in Eq. (10) is a monotone increasing function of $T$. That is,

$$
\partial \gamma_{A}^{x} / \partial T>0
$$

The rationale behind Eq. (16) is that the consumers may update their pre-alliance beliefs about $x$ of $A$ more if there exists a higherlevel of product involvement in the co-brand's category. In this case, one can show that $\partial S^{\alpha} /$ $\partial T>0$. That is, an amplified reciprocal effect on the belief level occurs. Assuming other things being the same, because $\partial S^{\beta} / \partial S^{\alpha}>0$, and thus $\partial S^{\beta} / \partial T>0$. That is, consumers will have an amplifying effect on the negative reciprocal effects on $A$ on the attitude level in the higher-involved scenario.

On the contrary, to prove Prop. 2, due to the need to be cautious in this model, co-branding beliefs are modeled as

$$
\begin{aligned}
& P_{A B(1)}^{x}=\operatorname{Max}\left[P_{A(1)}^{x}, P_{B(1)}^{x}\right], \\
& P_{A B(1)}^{y}=\operatorname{Mix}\left[P_{A(1)}^{y}, P_{B(1)}^{y}\right] .
\end{aligned}
$$

As mentioned in Section 2, Nkwocha et al. (2005) have inferred that, when a lower-involvement case occurs, consumers can consider the positive co-branding attribute information more important. Hence, to prove Prop. 2, we denote $T$ as the differential level of product involvement, and assume that $\gamma_{A}^{x}$ in Eq. (10) is a monotone decreasing function of $T$. That is

$$
\partial \gamma_{A}^{x} / \partial T<0 .
$$

The rationale behind Eq. (19) is that the consumers may update their pre-alliance beliefs about $x$ of $A$ more if there exists a lower-level of product involvement on the product category of the co-brand. In this case, by using the same logic as proving Prop. 1, we can show $\partial S^{\alpha} / \partial T<0$ and $\partial S^{\beta} / \partial T<0$. That is, consumers will have an amplifying effect on the positive reciprocal effects on $A$ on the atti- 
tude level in the lower-involved scenario.

\section{Conclusions, Contributions, and Limitations}

This research enhances the importance of $\mathrm{co}^{-}$ branding (cf. Lanseng and Olsen 2012), and answers an important question: How does consumer product involvement moderate the strength of reciprocal effect on each partnering brand? Specifically, we explored whether the higherinvolved and lower-involved categories affect the magnitude of reciprocal effects. Based on a review of relevant literature, we formulated two research propositions. Proposition 1 illustrates that the negative reciprocal effect on partnering brands is stronger in the scenario of higherinvolved categories than in lower-involved categories. In contrast, Proposition 2 argues that the positive reciprocal effect on partnering brands is more significant in the case of lowerinvolved categories than in higher-involved categories. We built a mathematical model to prove these two theory-driven propositions.

This research makes two distinct contributions to the co-branding research field. First, we echo the importance of consumer product involvement (Helmig et al. 2007), and expand on Walchli's (2007) study to investigate the influence of product involvement on reciprocal effects in the scenario of a moderately-incongruent brand pair (i.e., a good product fit). Second, we are the first to use a theoretical mathematical approach for investigating the influence of product involvement on co-branding evaluation; by so doing, we can help managers to identify key decision variables in their decision-making processes. For branding managers, we offer a normative guideline of alliance formation. We argue that a lower-involved product (e.g., a recordable $\mathrm{CD}$, which is often a cheap product) may generate benefits in terms of brand image; on the other hand, a higher-involved product (e.g., a smart-phone) may be harmful to a brand image.

This study is not without limitations. First, a critical limitation is that the two theoreticaldriven propositions have not yet been empirically validated. We will bridge this gap either by providing a meta-analytical literature study or by empirically testing corresponding propositions. Besides, due to the lack of supporting arguments and the need to be cautious in our modeling approach (cf. Moorthy 1993; Venkatesh et al. 2000), we did not discuss whether the positive (negative) reciprocal effect is stronger in the higher(lower)-involved scenario than in the lower(higher)-involved case. However, based on Goldsmith and Flynn's (1992) findings, we predict that a larger positive reciprocal effect also occurs in the higher-involved case. Future research may explore this interesting issue.

Furthermore, we formulate consumer involvements $(T)$ in our model as an important parameter of the updating weight of attribute 
beliefs $\left(\gamma_{F}^{x}\right)$. However, consumer involvements may affect other variables in our model, such as the weight of existing beliefs about the two brands $\left(\kappa_{F}^{H, U}\right)$ (cf. Simonin and Ruth 1998). ${ }^{2)}$ Future studies could perform an experiment for bridging this gap. Finally, the magnitude of the reciprocal effect can be also affected by different levels of brand familiarity (Simonin and Ruth, 1998), and future studies could address this issue as well.

〈Received January 26. 2016〉

〈Revised September 9. 2016〉

$\langle$ Accepted October 5. 2016〉

\section{References}

Aaker, D. A., \& Keller, K. L. (1990). Consumer evaluations of brand extensions. Journal of Marketing, 54(1), 27-41.

Anderson, N. H. (1981). Foundation of Information Integration Theory. New York: Academic Press.

Bass, F. M., \& Talarzyk, W. W. (1972). An attitude model for the study of brand preferences. Journal of Marketing Research, 9(1), 93-96.

Baumgarth, C. (2004). Evaluations of co-brands and spill-over effects: further empirical results. Journal of Marketing Communications,
10(2), 115-131.

Bengtsson, A., \& Servais, P. (2005). Co-branding on industrial markets. Industrial Marketing Management, 34(7), 706-713.

Bouten, L. M., Snelders, D., \& Hultink, E. J. (2011). The impact of fit measures on the consumer evaluation of new co-branded products. Journal of Product Innovation Management, 28(4), 455-469.

Bucklin, L. P., \& Sengupta, S. (1993). Organizing successful co-marketing alliances. Journal of Marketing, 57(2), 32-46.

Cao, Z., \& Sorescu, A. (2013). Wedded bliss or tainted love? stock market reactions to the introduction of cobranded products. Marketing Science, 32(6), 939-959.

Cook, K. S. (1977). Exchange and power in networks interorganizational relations. The Sociological Quarterly, 18(1), 62-82.

Cunha Jr., M., Forehand, M. R., \& Angle, J. W. (2015). Riding coattails: when co-Branding helps versus hurts less-known brands. Journal of Consumer Research, 41(5), 1284-1300.

Geylani, T., Inman, J. J., \& Hofstede, F. T. (2008). Image reinforcement or impairment: the effects of co-branding on attribute uncertainty. Marketing Science, 27(4), 730744.

Goldsmith, R., \& Flynn, L. (1992). Identifying innovators in consumer product markets. European Journal of Marketing, 26(12),

2) We thank one of the anonymous reviewers for pointing out this important and interesting issue. 
42-55.

Hadjicharalambous, C. (2013). A unified framework for evaluating brand alliances and cobranding strategies: implications and future directions. Academy of Marketing Studies Journal, 17(2), 13-26.

Helmig, B., Huber, J. A., \& Leeflang, P. S. H. (2007). Explaining behavioural intentions toward co-branded products. Journal of Marketing Management, 23(3/4), 285-304.

Helmig, B., Huber, J. A., \& Leeflang, P. S. H. (2008). Co-branding: the state of the art. Schmalenbach Business Review, 60(3), 359377.

Hillyer, C., \& Tikoo, S. (1995). Effect of cobranding on consumer product evaluations. Advances in Consumer Research, 22(1), 123-127.

James, D. (2005). Guilty through association: brand association transfer to brand alliances. Journal of Consumer Marketing, 22(1), $14-24$.

Janiszewski, C., \& van Osselaer, S. M. J. (2000). A connectionist model of brand associations. Journal of Marketing Research, 37(3), 331350.

Krugman, H. E. (1966). The measurement of advertising involvement. Public Opinion Quarterly, 30(4), 583-596.

Lanseng, E. J., \& Olsen, L. E. (2012). Brand alliances: the role of brand concept consistency. European Journal of Marketing, 46 (9), 1108-1126.
Laurent, G., \& Kapferer, J. N. (1985). Measuring consumer involvement profiles. Journal of Marketing Research, 22(1), 41-53.

Lee, C. L., \& Decker, R. (2016). Co-branding partner selection: the importance of belief revision. Journal of Business Economics and Management, 17(4), 546-563.

Lee, J. K., Lee, B. K., \& Lee, W. N. (2013). Country-of-origin fit's effect on consumer product evaluation in cross-border strategic brand alliance. Journal of Business Research, 66(3), 354-363.

Levin, I. P., \& Levin, A. M. (2000). Modeling the role of brand alliances in the assimilation of product evaluations. Journal of Consumer Psychology, 9(1), 43-52.

Mazodier, M., \& Merunka, D. (2012). Achieving brand loyalty through sponsorship: the role of fit and self-congruity. Journal of Academy of Marketing Science, 40(6), 807-820.

Meyers-Levy, J., \& Tybout, A. M. (1989). Schema congruity as a basis for product evaluation. Journal of Consumer Research, 16(1), 39-54.

Michaelidou, N., \& Dibb, S. (2006). Product involvement: an application in clothing. Journal of Consumer Behaviour, 5(5), 442453.

Mittal, B., \& Lee, M.-S. (1989). A causal model of consumer involvement. Journal of ECOnomic Psychology, 10(3), 363-389.

Mittal, V., Ross, W. T., \& Baldasare, P. M. (1998). The asymmetric impact of negative and 
positive attribute-level performance on overall satisfaction and repurchase intentions. Journal of Marketing, 62(1), 33-47.

Mohr, J., \& Spekman, R. (1994). Characteristics of partnership success: partnership attributes, communication behavior, and conflict resolution techniques. Strategic Management Journal, 15(2), 135-152.

Moorthy, K. S. (1993). Theoretical modeling in marketing. Journal of Marketing, 57(2), 92-106.

Nkwocha, I., Bao, Y., Brotspies, H. V., \& Johnson, W. C. (2005). Product fit and consumer attitude toward brand extensions: the moderating role of product involvement. Journal of Marketing Theory and Practice, 13(3), 49-61.

Newmeyer, C., Venkatesh, R., \& Chatterjee, R. (2014). Co-branding arrangements and partner selection: a conceptual framework and managerial guidelines. Journal of Academy of Marketing Science, 42(2), 103-118.

Park, C. W., Jun, S. Y., \& Shocker, A. D. (1996). Composite branding alliances: an investigation of extension and feedback effects. Journal of Marketing Research, 33 (4), 453-466.

Radighieri, J. P., Mariadoss, B. J., Grégoire, Y., \& Johnson, J. L. (2013). Ingredient branding and feedback effects: the impact of product outcomes, initial parent brand strength asymmetry, and parent brand role. Marketing Letters, 25(2), 123-138.
Rao, A. R., \& Ruekert, R. W. (1994). Brand alliances as signals of product quality. Sloan Management Review, 36(1), 87-97.

Rodrigue, C. S., \& Biswas, A. (2004). Brand alliance dependency and exclusivity: an empirical investigation. Journal of Product \& Brand Management, 13(7), 477-487.

Rothschild, M. L. (1979). Marketing communications in nonbusiness situations or why it's so hard to sell brotherhood like soap. The Journal of Marketing, 43(2), 11-20.

Samuelsen, B. M., Olsen, L. E., \& Keller, K. L. (2014). The multiple roles of fit between brand alliance partners in alliance attitude formation. Marketing Letters, 26(4), 619629.

Simonin, B. L., \& Ruth, J. A. (1998). Is a company known by the company it keeps? assessing the spillover effects of brand alliances on consumer brand attitudes. Journal of Marketing Research, 35(1), 30-42.

Spence, M. (1973). Job market signaling. The Quarterly Journal of Economics, 87(3), 355374.

Sreejesh, S. (2012). Consumers' evaluation of $\mathrm{co}^{-}$ brand extensions: the effects of concept congruity on the evaluation of co-branded products, analyzing the moderating role of task involvement. International Management Review, 8(1), 21.

Swaminathan, V., Reddy, S. K., \& Dommer, S. (2011). Spillover effects of ingredient branded strategies on brand choice: a field study. 
Marketing Letters, 23(1), 237-251.

Tyebjee, T. T. (1979). Response time, conflict, and involvement in brand choice. Journal of Consumer Research, 6(3), 295-304.

Vaidyanathan, R., \& Aggarwal, P. (2000). Strategic brand alliances: implications of ingredient branding for national and private label brands. Journal of Product and Brand Management, 9(4), 214-228.

Van der Lans, R., Van den Bergh, B., \& Dieleman, E. (2014). Partner selection in brand alliances: an empirical investigation of the drivers of brand fit, Marketing Science, 33(4), 551-566.

Venkatesh, R., Mahajan, V., \& Muller, E. (2000). Dynamic co-marketing alliances: when and why do they succeed or fail. International Journal of Research in Marketing, 17(1), 3-31.

Vijay, G. H., Bezawada, R., \& Talukdar, D. (2012). Trial, repeat purchase and spillover effects of cobranded extensions. Journal of Product \& Brand Management, 21(2), 7688.
Voss, K. E., \& Tansuhaj, P. (1999). A consumer perspective on foreign market entry: building brands through brand alliances. Journal of International Consumer Marketing, 11(2), 39-58.

Walchli, S. B. (2007). The effects of betweenpartner congruity on consumer evaluation of co-branded products. Psychology and Marketing, 24(11), 947-974.

Walchli, S. B. (2015). A typology of co-branding strategies. Paper presented at the annual meeting of Atlantic Marketing Association, Savannah, GA.

Washburn, J. H., Till, B. D., \& Priluck, R. (2000). Co-branding: brand equity and trial effects. Journal of Consumer Marketing, 17(7), 591-604.

Washburn, J. H., Till, B. D., \& Priluck, R. (2004). Brand alliance and customer-based brand-equity effects. Psychology and Marketing, 21(7), 487.

Zaichkowsky, J. L. (1985). Measuring the involvement construct. Journal of Consumer Research, 12(3), 341-352. 